U.S. DEPARTMENT OF THE INTERIOR

U.S. GEOLOGICAL SURVEY

MAP SHOWING THE DISTRIBUTION OF ANOMALOUS CONCENTRATIONS OF GOLD AND SILVER IN STREAM SEDIMENT, HEAVY-MINERAL

CONCENTRATE, AND AQUATIC MOSS IN THE

IDITAROD QUADRANGLE, ALASKA

By John E. Gray, J.M. Motooka, and R.M. O'Leary 


\section{INSERT FOR MF-2219-D}

Corrections and additions for: U.S. Geological Survey Miscellaneous Field Studies Map MF-2219-D, Map showing the distribution of anomalous concentrations of gold and silver in samples of stream sediment, heavy-mineral concentrate, and aquatic moss in the Iditarod quadrangle, Alaska

In the References section, the title of Miller and Bundtzen (1994) is incorrect and the correct reference is:

Miller, M.L., and Bundtzen, T.K., 1994, Generalized geologic map of the Iditarod quadrangle, Alaska, showing potassium-argon, major-oxide, trace-element, fossil, paleocurrent, and archaeological sample localities: U.S. Geological Survey Miscellaneous Field Studies Map MF-2219-A, 1 plate, scale 1:250,000, 48 p.

The geologic base for the map and the geologic descriptions in the Description of Map Units section are from Miller and Bundtzen (1994). 